\title{
Avulsion amputation of the ring finger managed by double cross finger flap: 25 years follow-up
}

\author{
Annavarapu Gopalakrishna \\ Department of Plastic Surgery, J W Global Hospital and Research Centre, Mount Abu, Rajasthan, Deccan College of Medical \\ Sciences, Hyderabad, Andhra Pradesh, India
}

Address for correspondence: Dr. A. Gopalakrishna, J W Global Hospital and Research Centre, Delwara Road, Mount Abu - 307501 , Rajasthan, India. E-mail: agkga@rediffmail.com

\section{ABSTRACT}

Avulsion amputation of the fingers are rare. Current trend is to replant the avulsed tissue in spite of a high rate of failure. There are situations where replantation is not possible. Various salvage procedures have been mentioned. The author is presenting a 25 year follow up of a double cross finger flap done in 1987. A similar procedure has been reported by other authors but with a short term follow up.

\section{KEY WORDS}

Double cross finger flap; long-term follow-up; ring avulsion; sandwich technique

\section{INTRODUCTION}

vulsion amputation of the fingers is fortunately rare. A forceful pull on a ring worn by a person can lead to a wide variety of injuries from a simple contusion to total degloving and amputation. Occasionally, the tendons may be avulsed. These injuries have been classified into three types based on circulatory status. Kay's classification takes into account the presence of skeletal injury. ${ }^{[1]}$ Current trend is to replant the avulsed tissue in spite of a high rate of failure. A number of additional procedures such as venous flaps and arterialised venous flaps have been reported by various authors. ${ }^{[2-5]}$

However, there is a group of patients where either the avulsed part is missing or mutilated and unsuitable for

\begin{tabular}{|l|l|}
\hline \multicolumn{2}{|c|}{ Access this article online } \\
\hline Quick Response Code: & Website: \\
\hline & www.ijps.org \\
\cline { 2 - 2 } & DOI: \\
\hline
\end{tabular}

revascularisation. Many grafts and local and distant flaps have been reported to cover the stump after avulsion of the ring finger in various combinations. These include split skin grafts, full thickness skin grafts, cross finger flaps, fillet flaps, local flaps from the hand and groin and abdominal flaps. ${ }^{[2-11]}$ There has also been a preference for a revision amputation due to poor results of attempts at reconstruction. ${ }^{[12]}$

The use of de-epithelialised flaps has been described for various applications including hand and finger injuries. ${ }^{[13,14]}$ In 2010 Abo-hashem Azab Moosa reported the use of double cross finger flaps to cover the stump of the injured finger in a series of 22 cases with good results followedup for a mean period of 6 months. ${ }^{[15]}$ The author has performed a similar procedure in three patients in 1987 , but was not able to follow these patients and hence could not publish his results. These cases were presented at the annual conference of the association of plastic surgeons of India at Baroda in 1988 as 'the sandwich technique'.

One of the patients returned to the hospital for some other reason in 2012 and provided us with an opportunity to see a 25 year follow-up of this technique. Hence, this case report is presented. 


\section{CASE REPORT}

A 33-year-old right handed male small time businessman presented with a history of injury to his left ring finger. His ring was caught in some part of a bus as he alighted and the bus moved forward pulling off his finger [Figure 1].

On examination, there was a total loss of the terminal phalanx and degloving of the middle phalanx. The flexor digitorum sublimis was intact and uninjured. The flexor digitorum profundus was pulled out (as reported by the patient).

It was decided to salvage the degloved middle phalanx using a cross finger flap each from the two adjoining fingers. The flap from the middle finger provided cover for the volar aspect and the tip of the ring finger. The de-epithelialised flap from the little finger was used to cover the dorsal aspect of the ring finger. The secondary defect was covered with a split skin graft from the thigh. The flaps were divided and set in after 3 weeks. The healing was primary and the recovery was uneventful [Figures 2 and 3]. After a month, the patient was given a locally manufactured inexpensive prosthesis made of polyvinylchloride on a trial basis. Silicon prosthesis was to be made to order if the patient found the prosthesis useful.

This patient was lost to follow-up at that time. In 2013, the patient brought his son, who had sustained burns, to the hospital to consult the author and we had an opportunity to see a long term follow-up of the procedure [Figures 4-7].

The cosmetic appearance of the finger was compromised because of the absence of the terminal phalanx. The grip was good demonstrating the value of saving the proximal inter phalangeal joint and a length of the middle phalanx. Although the author was trying to save a stump for accommodating prosthesis, the patient seemed to be more comfortable without one. This was one of the reasons that he did not come for follow-up.

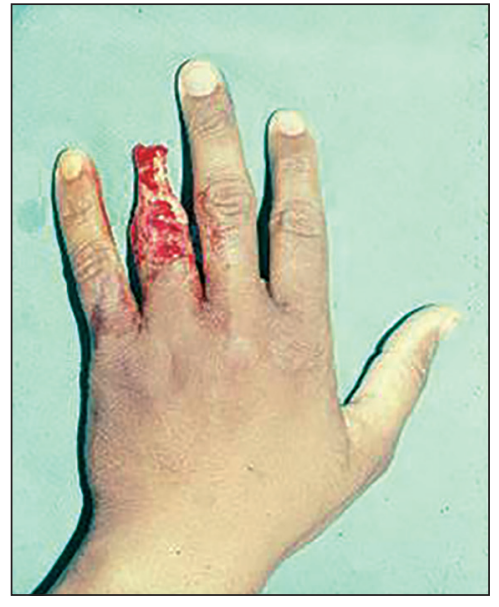

Figure 1: Ring avulsion injury

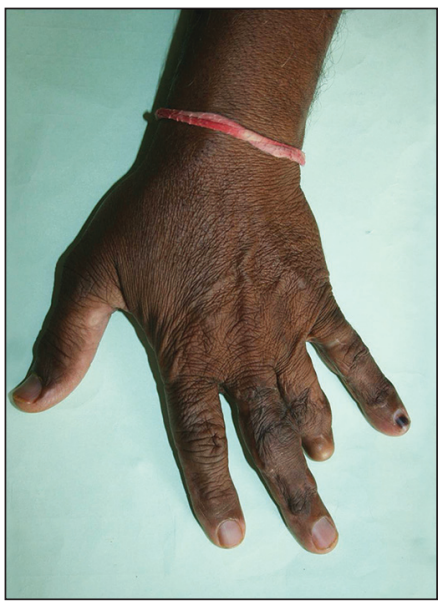

Figure 4: A 25 year follow-up

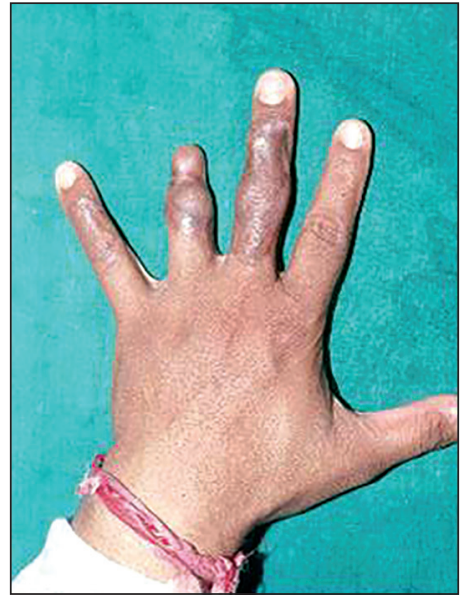

Figure 2: Post operative

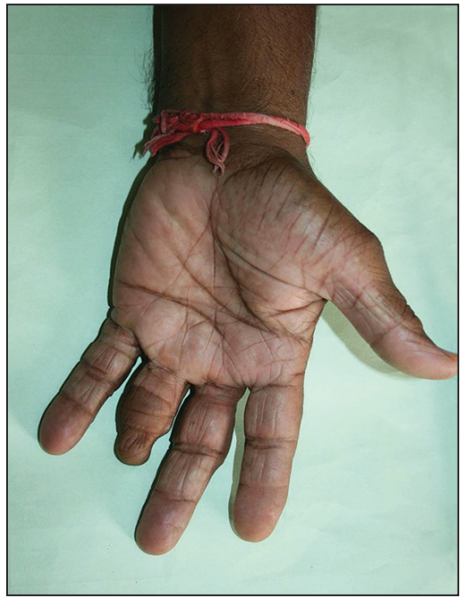

Figure 5: A 25 year follow-up - open hand

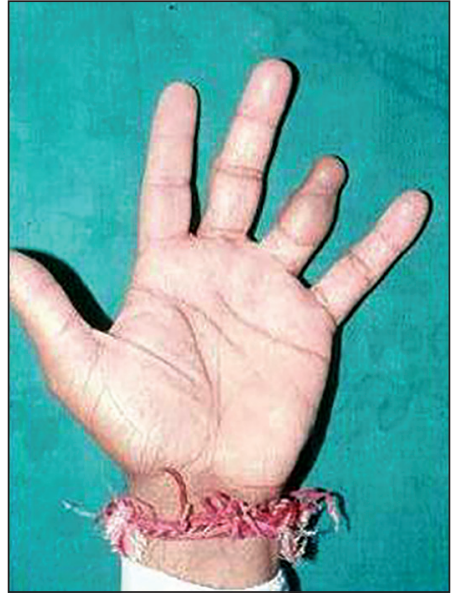

Figure 3: Post-operative

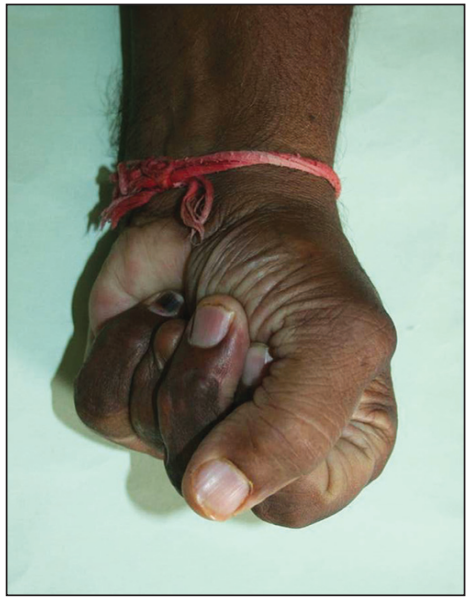

Figure 6: A 25 year follow-up complete fist 


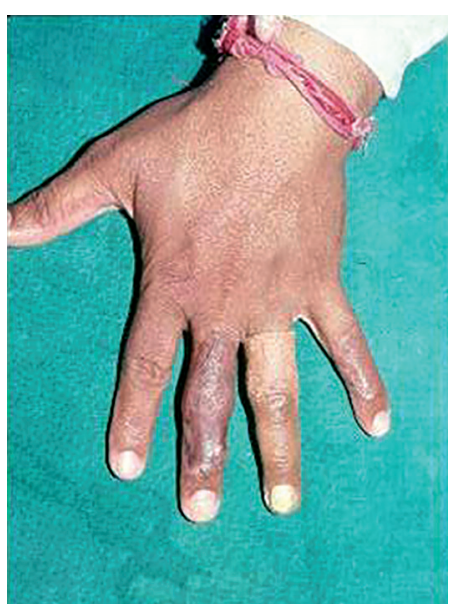

Figure 7: open hand with temporary prosthesis for dress occasions

\section{DISCUSSION}

Ring avulsion amputation is a rare injury. At workplace, the injury occurs when a ring worn by a person gets caught in the moving part of a machine. We have seen patients who were injured when the ring was caught in a moving vehicle, while the person wearing the ring was alighting.

The severity of the injury varies from bruising to total amputation of the terminal phalanx and degloving of the middle phalanx, as was the case in this patient.

Replantation of the digit or revascularisation of the avulsed soft tissue is the first choice in management. This may sometimes require additional procedures like vein grafts or flaps.

Where replantation is not possible because of mutilation or loss of tissue, attempt should be made to save the length of the finger. The tissue closest to the defect is the best in terms of colour and texture match and causes least inconvenience of immobilisation. For that reason the author chose to use cross finger flaps to cover the stump. The recovery was uneventful and a short term followup showed a good result. The patient was also provided with a low tech low cost prosthesis. A better prosthesis was to be made once the patient was satisfied about its usefulness. The patient decided that he felt better without the prosthesis and hence did not attend follow-up.

Cosmetic prostheses in fingers are not very popular with working class patients in India because they hamper function.

\section{CONCLUSION}

Many procedures are available for the salvage of a non replantable ring avulsion injury. In our hands, the simple procedure of cross finger flaps has given a good longterm result. The hand has acceptable function. Although the intention was to provide a stump on which the patient could wear prosthesis the patient chose to avoid the latter.

\section{REFERENCES}

1. Sabapathy SR, Venkatramani H, Ravindra Bharathi $R$, Sebastin SJ. Replantation of ring avulsion amputations. Indian J Plastic Surg 2003;36:76-83.

2. Fejjal N, Belmir R, El Mazouz S, Gharib NE, Abbassi A, Belmahi AM. Finger avulsion injuries: A report of four cases. Indian J Orthop 2008;42:208-11.

3. Brooks D, Buntic RF, Kind GM, Schott K, Buncke GM, Buncke HJ. Ring avulsion: injury pattern, treatment, and outcome. Clin Plast Surg 2007;34:187-95, viii.

4. Adani R, Marcoccio I, Castagnetti C, Tarallo L. Long-term results of replantation for complete ring avulsion amputations. Ann Plast Surg 2003;51:564-8.

5. Adani R, Pataia E, Tarallo L, Mugnai R. Results of replantation of 33 ring avulsion amputations. J Hand Surg Am 2013;38:947-56.

6. McGeorge DD, Stilwell JH. The management of the complete ring avulsion injury. J Hand Surg Br 1991;16:413-4.

7. Brooks D, Buntic RF, Taylor C. Use of the venous flap for salvage of difficult ring avulsion injuries. Microsurgery 2008;28:397-402.

8. Kong BS, Kim YJ, Suh YS, Jawa A, Nazzal A, Lee SG. Finger soft tissue reconstruction using arterialized venous free flaps having 2 parallel veins. J Hand Surg Am 2008;33:1802-6.

9. Gravvanis A, Kakagia D, Tsoutsos D. Reverse flow free fillet flap to resurface ring finger avulsion injury. Microsurgery 2012;32:418-9.

10. Demiri EC, Dionyssiou DD, Biskiniotis I, Papadimitriou D. Reconstruction of a degloved finger with a heterodigital reverse dorsal digitometacarpal flap. Scand J Plast Reconstr Surg Hand Surg 2007;41:42-4.

11. Hashem AM. Salvage of degloved digits with heterodigital flaps and full thickness skin grafts. Ann Plast Surg 2010;64:155-8.

12. Segret J, Barbary S, Pétry D, Dautel G. Primary ray resection as an alternative to microsurgical replantation in the management of ring finger avulsion. Chir Main 2008;27:202-7.

13. Fejjal N, Belmir R, El Mazouz S, Gharib N, Abbassi A, Belmahi A. Reversed cross finger subcutaneous flap: A rapid way to cover finger defects. Indian J Plast Surg 2008;41:55-7.

14. Thatte RL, Gopalakrishna A, Prasad S. The use of deepithelialised "turn over" flaps in the hand. Br J Plast Surg 1982;35:293-9.

15. Abo-hashem Azab Moosa A. Double cross-finger flaps: a novel technique for management of ring avulsion injuries. Ann Plast Surg 2010;64:409-11.

How to cite this article: Gopalakrishna A. Avulsion amputation of the ring finger managed by double cross finger flap: 25 years follow-up. Indian J Plast Surg 2014;47:444-6.

Source of Support: Nil, Conflict of Interest: None declared. 